6. Sizonenko O., Zaichenko A., Torpakov A. et al. Pulsed-discharged technology of metal-matrix composite materials obtainment. Materials Science. Non-equilibrium phase transformations. 2015. Vol. 1, No. 1. P. 15-18.

DOI https://doi.org/10.30525/978-9934-26-046-9-18

\title{
ВЛАСТИВОСТІ ДИФУЗІЙНИХ ЗАХИСНИХ ПОКРИТТІВ НА ОСНОВІ ХРОМУ ТА КРЕМНЮЮ НА ВУГЛЕЦЕВИХ СТАЛЯХ
}

\author{
Янцевич К. В. \\ молодший науковий співробітник \\ Інститут електрозварювання імені С. О. Патона \\ Національної академії наук України \\ м. Київ, Украӥна
}

Відомо, що нанесення на поверхню сталей та сплавів дифузійних покриттів призводить до підвищення їх твердості, міцності зносостійкості, жаростійкості та корозійної стійкості у різних агресивних середовищах[1-5]. Фізико - хімічні властивості та корозійна стійкість таких покриттів залежить від складу дифузійних шарів, способу та режиму отримання, марки оброблюваної сталі, природи агресивного середовища. Комплексне насичення хромом та кремнієм дозволяє формувати на поверхні вуглецевих сталей двокомпонентні дифузійні шари, які володіють поліпшеними захисними властивостями в порівняні з однокомпонентними кремнієвими та хромовими покриттями.

В роботі представлені результати фізико-хімічних властивостей хромосиліцидних покриттів та вплив їх на корозійну стійкість у деяких агресивних середовищах.

Для нанесення покриттів використовували спеціальну установку, яка була виготовлена на базі шахтної печі СШОЛ 1.1.6/12. Процес проводили при температурі 1200-1400К при парціальному тиску в реакційний камері $10^{2}$ Па 3 використанням порошків феросиліцію марки ФС - 90, хрому марки X-2, чотирихлористого вуглецю та графіту. В конструкцію робочої камери при нанесенні хромосиліцидного покриття вперше було застосовано реакційний стакан з графітовим дном [6], що дало можливість підвищити активність газової фази та 
пришвидшити процес формування дифузійних шарів. Дослідження мікроструктури покриттів проводили на оптичному мікроскопі «Neophot 21». Рентгеноструктурний аналіз проводили на установці ДРОН 3-M у монохроматичному $\mathrm{CuK}_{a}$ випромінюванні. Хімічний склад покриттів визначали мікрорентгеноспектральним аналізом 3 використанням енергодисперсійної приставки Energy 200 до скануючого електронного мікроскопу CamScan 4D з програмою обробки результатів INCA 200, похибка вимірювань \pm 0,3 \% «. Корозійні випробування проводили у $10 \%$ сульфатній, соляній, оцтовій, нітратній кислотах. Час корозійних випробувань складав $24-196$ години при $18{ }^{\circ} \mathrm{C}$.

Встановлено, що комплексні покриття за участю хрому та кремнію, нанесенні на поверхню сталі 45, згідно даним мікроструктурного аналізу (рис.1), складаються 3 двох зон, які розташовані паралельно поверхні насичення.

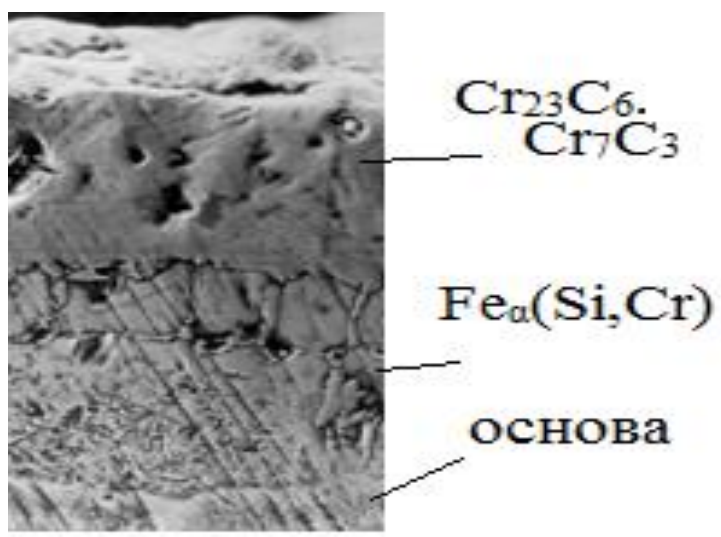

Рисунок 1. Мікроструктура сталі 45 з комплексним покриттям на онові хрому та кремнію (x500)

Рентгеноструктурним пошаровим аналізом встановлено, що на поверхні зразків, отриманих покриттів утворюється карбід хрому $\mathrm{Cr}_{23} \mathrm{C}_{6}$ (a=1,0627 нм). 


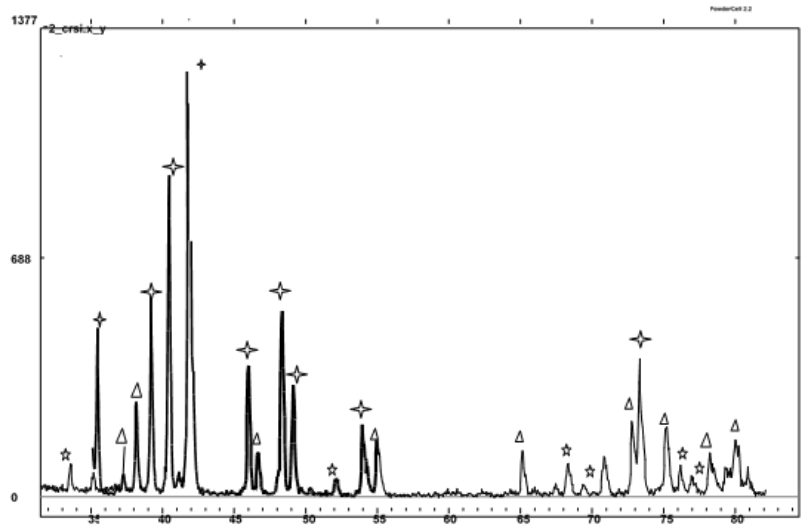

Рисунок 2. Фрагмент дифрактограми покриття на основі хрому та кремнію на сталі 45 . $\mathrm{Cu}-\mathrm{K}_{\mathbf{a}}$-випромінювання. $\left(\triangle \mathrm{Cr}_{7} \mathrm{C}_{3}\right.$, $\& \mathrm{Cr}_{23} \mathrm{C}_{6}$, 文 $\left.-\mathrm{Fe \alpha}(\mathrm{Cr}, \mathrm{Si})\right)$

Після зняття 3 поверхні 10,0-12,0 мкм додатково з'являються піки, що належать ОЦК гратці $\alpha-\mathrm{Fe}(\mathrm{a}=0,2866$ нм). Подальше зняття шарів покриття (до 15 мкм) супроводжується посиленням дифракційних максимумів, що належать ОЦК гратці $\alpha$-Fe i поступовим зникненням піків, що належать карбіду хрому $\mathrm{Cr}_{23} \mathrm{C}_{6}$. При цьому, на дифрактограмах фіксуються слабкі піки, що належать карбіду хрому $\mathrm{Cr}_{7} \mathrm{C}_{3}$ $(\mathrm{a}=0,6999$ нм, $\mathrm{B}=1,2185$ нм, $\mathrm{c}=0,4514$ нм $)$. Деякі відхилення для одержаних покриттів значень параметрів кристалічної гратки карбідів $\mathrm{Cr}_{7} \mathrm{C}_{3}, \mathrm{Cr}_{23} \mathrm{C}_{6}$ від характерних для полікристалічних карбідів можливо пов'язані з легуванням карбідних фаз кремнієм та залізом, $\alpha$-Fe - кремнієм та хромом.

Мікрорентгеноспектральним аналізом встановлено, що на зовнішній зоні покриття, на основі карбідів хрому $\mathrm{Cr}_{23} \mathrm{C}_{6}$, міститься до $52,87 \%$ ат. хрому, крім того в ній розчиняється невелика кількість кремнію (до $0,15 \%$ ат.) та залізо (до 15,73 \% ат.). Безпосередньо під нею розташовується зона на основі $\alpha$-заліза, яка містить 9,87 - 5,55\% ат. хрому, $8,15-3,89 \%$ ат. кремнію, $72,47-84,69 \%$ ат. заліза. Товщина покриттів на сталі 45 сягала $120 \cdot 10^{-6}$ м, мікротвердість 19,5 ГПа

Проведені в роботі корозійні дослідження та отримані раніше [7] показали, що менш стійкими виявилися дифузійні покриття у розчинах сульфатної та соляної кислотах, а найбільш стійкими - у розчинах нітратної кислоти. Так, у 10 \% розчинах сульфатної, соляної, оцтової, 
нітратної кислоти покриття гальмує швидкість корозії сталі 45, відповідно, у 4,5; 4; 17 та 9090 раз. Тривала витримка зразків у кислотах (більше 196 годин для соляної кислоти) призводить до відшарування дифузійних шарів та пришвидшенню корозії внаслідок утворення гальванічної пари метал - покриття.

Додатково підвищити корозійну стійкість дифузійних покриттів, нанесених на вуглецеві сталі можливо за рахунок високотемпературного окислення. Проведені корозійні іспити показали, що окислені на протязі 3 годин при температурі $1023 \mathrm{~K}$ покриття, зменшують швидкість корозії сталі 45 у 10\% $\mathrm{H}_{2} \mathrm{SO}_{4}$ у1510 раз, відповідно.

Висновки. Показано, що хромосиліцидні покриття складаються 3 дифузійних шарів, в склад яких входять карбіди хрому $\mathrm{Cr}_{23} \mathrm{C}_{6} \mathrm{Ta} \mathrm{Cr}_{7} \mathrm{C}_{3}$ (зовнішній) та твердий розчин кремнію і хрому в $\alpha$-Fe (перехідній) зоні. Товщина покриттів на сталі 45 сягала $120 \cdot 10^{-6}$ м, мікротвердість - 19,5 ГПа.

Встановлено, що високу корозійну стійкість хромосиліцидні покриття мають у розчинах азотної кислоти. Додатково підвищити корозійну стійкість покриттів можливо за рахунок високотемпературного окислення.

\section{Література:}

1. Земсков Г. В., Коган Р. А. Многокомпонентное диффузионное насыщение металлов и сплавов. М. Металлургия, 1978. 208 с.

2. Лоскутов В.Ф., Хижняк В.Г., Погребова І.С., Горбатюк Р.М., Бочар І.Й. Карбідні покриття на сталях і твердих сплавах. Тернопіль, 1998. $144 \mathrm{c}$.

3. Мельник П.И. Диффузионное насыщение железа и твердофазные превращения в сплавах. М.Металлургия, 1993. 128 с.

4. Ворошнин Л.Г., Менделеева О.Л., Сметкин В.А. Теория и технология химико-термической обработки. Минск, 2010. 304 с.

5. Похмурский В.И., Мокрова Л.М., Далисов В.Б. Распределение элементов в диффузионных слоях при хромосилицировании. Защитные покрытия на металлах. 1973. № 7. С.144-146.

6. Спосіб нанесення карбідних покриттів. Пат. на винахід 50193А України: МПК (2002) С23С12/00. власник НТУУ «КПІ»; заявл. 16.11.2001; опубл. 15.10.2002, Бюл. № 10. 4c.

7. Погребова И.С., Янцевич К.В., Гарбуз В.М., Корниенко В.В. Влияние легированных хромом силицидных покрытий на кислотную коррозию углеродистых стали 08 КП. Фізико-хімічна механіка матеріалів. Спеціальний випуск. 2001. № 2. С. 108-113. 